\title{
Mycobacterium tuberculosis Complex Measurement
}

National Cancer Institute

\section{Source}

National Cancer Institute. Mycobacterium tuberculosis Complex Measurement. NCI

Thesaurus. Code C128983.

The determination of the amount of mycobacterium tuberculosis complex present in a sample. 